\title{
PENGARUH STATUS GIZI DAN STIMULASI IBU TERHADAP TUMBUH KEMBANG BALITA DI PAUD AL IKHLAS KELURAHAN PADANG BULAN KECAMATAN MEDAN BARU KOTA MEDAN
}

\author{
Eva Mahayani, Dewi Meliasari, Wildan \\ Jurusan kebidanan Medan
}

\begin{abstract}
Abstrak
Upaya pengembangan kualitas SDM dengan mengoptimalkan potensi tumbuh kembang anak.Pertumbuhan dan perkembangan anak merupakan hasil interaksi antara faktor genetik-herediter- konstitusi dengan faktor lingkungan. Peran orang tua dalam mendukung pertumbuhan dan perkembangan anak sangat penting, dimana orang tua bisa menyediakan sarana untuk tumbuh dan berkembang dengan baik dan sempurna. Pertumbuhan dan perkembangan balita dapat tumbuh secara optimal bila orang tua dapat mengasuh balitanya dengan benar, pemeliharaan kesehatan yang memadai, memberikan gizi yang adekuat, kondisi lingkungan yang bersih dan merangsang atau menstimulasi yang terarah kepada balitanya sesuai dengan usia dalam semua aspek perkembangan baik motorik kasar, motorik halus, bahasa dan personal social. Tujuan penelitian ini adalah untuk melihat Pengaruh Status Gizi Dan Stimulasi Balita Terhadap Tumbuh Kembang Balita di Paud Al Ikhlas Kelurahan Padang Bulan Kecamatan Medan Baru Kota Medan Tahun 2016. Penelitian ini merupakan penelitian survei dengan pendekatan cross sectional. Penelitian ini dilalakukan di PAUD Al Ikhlas Kelurahan Padang Bulan Kecamatan Medan Baru Kota Medan.dengan sampel berjumlah 69orang yang diambil dengan teknik simple random sampling. Analisis data menggunakan uji regresi logistic berganda.Berdasarkan analisis bivariat didapat hasil ada hubungan antara status gizi dengan tumbuh kembang balita dengan nilai $p<0,001$, ada hubungan antara stimulasi ibu dengan tumbuh kembang balita dengan nilai $p<0,001$, dan dari analisis multivariat didapatkan hasil status gizi dan stimulasi ibu berpengaruh terhadap tumbuh kembang balita dengan nilai $\operatorname{Exp}(B)=38,650$ untuk status gizi dan $\operatorname{Exp}(B)=59,848$ untuk stimulasi.Saran kepada orang tua untuk menjaga tumbuh kembang anak, memberikan stimulas sesuai tumbuh kembang anak dan meningkatkan peran ibu untuk mencari informasi tentang perkembangan anak.
\end{abstract}

Kata Kunci : Status Gizi, Stimulasi, Tumbuhkembang

\section{PENDAHULUAN}

Kesehatan merupakan hak azasi manusia dan sekaligus sebagai investasi, Sumber daya manusia yang sehat dan berkualitas merupakan modal utama atau investasi dalam pembangunan kesehatan. Ukuran kualitas SDM dapat dilihat pada Indeks Pembangunan Manusia (IPM), sedangkan ukuran kesejahteraan masyarakat antara lain dapat dilihat pada tingkat kemiskinan dan status gizi masyarakat. Upaya pengembangan kualitas SDM dengan mengoptimalkan potensi tumbuh kembang anak dapat dilaksanakan secara merata apabila sistem pelayanan kesehatan yang berbasis masyarakat dapat dilakukan secara efektif dan efisien dan dapat menjangkau semua sasaran yang membutuhkan layanan (Depkes RI, 2006).

Salah satu upaya untuk meningkatkan kualitas sumber daya manusia adalah melalui peningkatan status gizi masyarakat, terganggunya perkembangan mental dan kecerdasan jika ditelusuri adalah akibat langsung maupun tidak langsung dari kekurangan asupan gizi dan ketersediaan pangan. Selain itu upaya-upaya untuk menciptakan generasi penerus bangsa yang sehat perlu diperhatikan terutama pada masa peka atau "masa keemasan" (golden period) yang terjadi pada usia 0-5 tahun . Pada masa tersebut status kesehatan anak erat kaitannya dengan proses tumbuh kembang anak sehingga gizi dan stimulasi atau rangsangan-rangsangan dari orang tua penting untuk memenuhi proses tumbuh kembang anak. (WHO, 2015),

Indikator SDGs untuk upaya kesehatan bayi dan balita mempunyai target pada tahun 2030 mengakhiri segala bentuk malnutrisi, termasuk mencapai target international 2025 untuk penurunan stunting dan wasting pada balita. Maka RPJM dan RENSTRA 2015-2019 membuat acuan menurunkan prevalensi kekurangan gizi $17 \%$ dan prevalensi stunting $28 \%$ pada tahun 2019. Sedangkan berdasarkan data Riset Kesehatan Dasar (Riskesdas) 2013 prevalensi beratkurang pada tahun 2013 adalah 19,6 persen, terdiri dari 5,7 persen gizi buruk dan 13,9 persen gizi kurang. Jika dibandingkan dengan angka prevalensi nasional tahun $2007(18,4 \%)$ dan tahun $2010(17,9 \%)$ terlihat 
meningkat. Perubahan terutama pada prevalensi gizi buruk yaitu dari 5,4 persen tahun 2007, 4,9 persen pada tahun 2010, dan 5,7 persen tahun 2013. Sedangkan prevalensi gizi kurang naik sebesar 0,9 persen dari 2007 dan 2013 . Hasil riskesdas pemantauan pertumbuhan balita yang dilakukan setiap bulan menunjukkan bahwa persentase balita umur 6-59 bulan yang tidak pernah ditimbang dalam enam bulan terakhir cenderung meningkat dari 25,5\% (2007), 23,8\% (2010) menjadi 34,3\% (2013).Berdasarkan data tersebut pemantauan untuk tumbuh kembang balita masih sangat rendah .

Pertumbuhan adalah bertambahnya ukuran dan jumlah sel serta jaringan intraseluler, berarti bertambahnya ukuran fisik dan struktur tubuh dalam arti sebagian atau keseluruhan, jadi bersifat kuantitatif sehingga dapat kita ukur dengan mempergunakan satuan panjang atau satuan berat Perkembangan ialah bertambahnya kemampuan struktur dan fungsi tubuh yang lebih kompelks , jadi bersifat kualitatif yang pengukurannya jauh lebih sulit daripada pengukuran pertumbuhan (Soetjiningsih,2010).

Pertumbuhan dan perkembangan anak merupakan hasil interaksi antara faktor genetik, herediter dengan faktor lingkungan. Faktor lingkungan inilah yang akan memberikan segala macam kebutuhan yang merupakan kebutuhan dasar yang diperlukan oleh anak untuk tumbuh dan berkembang yaitu kebutuhan fisik biomedis (asuh), kebutuhan kasih sayang ( asih ) dan stimulasi ( asah ) (Soetjiningsih,2010).

Peran orang tua dalam mendukung pertumbuhan dan perkembangan anak sangat penting. Dimana orang tua bisa menyediakan sarana untuk tumbuh dan berkembang dengan baik dan sempurna. Pertumbuhan dan perkembangan balita dapat tumbuh secara optimal bila orang tua dapat mengasuh balitanya dengan benar, pemeliharaan kesehatan yang memadai, memberikan gizi yang adekuat, kondisi lingkungan yang bersih dan merangsang atau menstimulasi yang terarah kepada balitanya sesuai dengan usia dalam semua aspek perkembangan baik motorik kasar, motorik halus, bahasa dan personal sosial. Selain itu juga peran sebagai tenaga kesehatan dapat memantau pertumbuhan dan perkembangan balita dengan memanfaatkan posyandu terintegrasi dengan mengaktifkan kegiatan bina keluarga balita serta pemberian Komunikasi Informasi dan Edukasi (KIE) tentang pertumbuhan dan perkembangan kepada orang tua khususnya ibu.

Berdasarkan penelitian Mahesa (2013) Hasil pelaksanaan KPSP didapatkan kemungkinan ada penyimpangan sebanyak 13 anak (20,3\%), perkembangan meragukan sebanyak 40 anak (62,5\%), perkembangn sesuai 11 anak (17,2\%). Menurut penelitian Dianita (2014) dengan pendekatan deskriftif tentang Studi tentang faktor - faktor yang mempengaruhi pertumbuhan dan perkembangan pada balita di desa Pengalangan rw 03 Menganti Gresik didapatkan hasil faktor stimulasi yang mempengaruhi sebanyak 23 responden $(82,1 \%)$ dan faktor gizi yang mempengaruhi sebanyak 22 responden $(78,6 \%)$.
Hasil penelitian Lindawati (2013) , satu variabel independen (status gizi) yang mempunyai hubungan bermakna dengan perkembangan motorik anak usia prasekolah dengan $\mathrm{p}=0,01$. Uji regresi logistik yang dilakukan untuk menentukan varibel yang paling berhubungan dengan perkembangan motorik anak usia prasekolah adalah variabel status gizi.

Berdasarkan uraian data yang dikemukakan diatas, maka peneliti tertarik untuk melakukan penelitian dengan judul : "Pengaruh Status Gizi Dan Stimulasi Ibu Terhadap tumbuh Kembang Balita di PAUD Al Ikhlas Kecamatan Padang Bulan Kota Medan Tahun 2016 “.

\section{Rumusan Masalah}

Berdasarkan uraian latar belakang diatas, yang menjadi rumusan masalah penelitian adalah apakah ada pengaruh status gizi dan stimulasi Ibu terhadap tumbuh kembang balita di PAUD Al Ikhlas Kelurahan Padang Bulan Kecamatan Medan Baru kota Medan tahun 2016.

\section{Tujuan Penelitian}

Adapun tujuan penelitian ini adalah untuk :

Melihat pengaruh status gizi dan stimulasi Ibu terhadap tumbuh kembang balita di PAUD Al Ikhlas Kecamatan Padang bulan kota Medan tahun 2016.

\section{Manfaat Penelitian :}

1. Hasil penelitian ini dapat digunakan sebagai data dan bahan masukan untuk perbaikan pemantauan tumbuh kembang balita agar tumbuh kembang balita menjadi lebih optimal.

2. Penelitian ini dapat digunakan sebagai bahan rujukan untuk penelitian selanjutnya yang berkaitan dengan pertumbuhan dan perkembangan balita.

\section{Metode}

Penelitian ini merupakan jenis penelitian survei dengan pendekatan cross sectional yaitu penelitian yang mempelajari hubungan dan faktor risiko dengan akibat yang berupa penyakit atau keadaan (status) kesehatan tertentu dalam waktu yang bersamaan (Nasir A dkk, 2011).

\section{Lokasi dan Waktu Penelitian Lokasi Penelitian}

Penelitian ini dilakukan di PAUD Al Ikhlas Kelurahan Padang Bulan Kecamatan Medan Baru Kota Medan tahun 2016.

\section{Waktu Penelitian}

Penelitian ini dilakukan dari proses pengajuan judul, pencarian literatur, proposal penelitian,pengumpulan data, pengolahan data, penyajian data, pembahasan, kesimpulan dan saran. Keseluruhan proses penelitian tersebut direncanakan akan dilakukan pada bulan Februari Oktober 2016.

\section{Populasi}

Populasi dalam penelitian ini Seluruh murid PAUD Al Ikhlas yang tercatat dalam register tahun 2016/2017 berjumlah 80 orang , 


\section{Sampel}

Sampel dalam penelitian ini adalah sebagian murid PAUD Al Ikhlas yang diambil menggunakan rumus isacc dan Michael (sugiyono, 2008):

$$
\mathrm{s}=\frac{\lambda^{2} \text {.N.P.Q }}{\mathrm{d}^{2}(\mathrm{~N}-1)+\lambda^{2} \cdot P \cdot Q}
$$

Berdasarkan perhitungan diatas maka besar sampel yang diambil 65 orang balita dan untuk mengambil sampel terpilih menggunakan simple ramdon sampling. dengan kriteria sampel usia anak minimal 24 bulan dan usia maksimal 60 bulan.

\section{HASIL}

\section{Karakteristik Responden}

Pada penelitian ini diperoleh pendidikan ibu lebih banyak tamat SMA/SMK sebanyak 33 orang $(47,8 \%)$, tamat sarjana sebanyak 19 orang $(27,5 \%)$, tamat Diploma sebanyak 10 orang $(14,5 \%)$ dan tamat SMP sebanyak 7 orang $(10,1 \%)$. Ibu lebih banyak mempunyai balita dengan jenis kelamin perempuan yaitu 44 orang $(63,8 \%)$ dan yang laki-laki sebanyak 25 orang $(36,2 \%)$.

Tabel 4.1 Distribusi Karakteristik Ibu Balita

\begin{tabular}{lcc}
\hline Karakteristik & $\begin{array}{c}\text { Jumlah } \\
(\mathbf{n})\end{array}$ & Persentase (\%) \\
\hline Pendidikan & 0 & 0 \\
SD & 7 & 10,1 \\
SMP & 33 & 47,8 \\
SMA/SMK & 10 & 14,5 \\
Diploma & 19 & 27,5 \\
Sarjana & & \\
Jenis Kelamin Balita & 25 & 36,2 \\
Laki-laki & 44 & 63,8 \\
Perempuan & $\mathbf{6 9}$ & $\mathbf{1 0 0 , 0}$ \\
\hline Total &
\end{tabular}

Berdasarkan Tabel 4.2 dapat dijelaskan bahwa umur ibu diperoleh nilai rata-rata 33,19 tahun dan standar deviasi 4,21 dengan nilai minimum 24 sampai nilai maksimum 42. Umur balita diperoleh nilai rata-rata 4,54 tahun dan standar deviasi 0,59 dengan nilai minimum 3 sampai nilai maksimum 6. Berat badan balita diperoleh nilai rata-rata $17,01 \mathrm{~kg}$ dan standar deviasi 2,80 dengan nilai minimum 10,0 sampai nilai maksimum 29,0. Kemudian tinggi badan balita diperoleh nilai rata-rata $109,89 \mathrm{~cm}$ dan standar deviasi 4,83 dengan nilai minimum 101,5 sampai nilai maksimum 120,0.

Tabel 4.2 Skor Pengukuran Umur Ibu, Umur Balita, Berat Badan dan Tinggi Badan

\begin{tabular}{lccccc}
\hline \multicolumn{1}{c}{ Variabel } & $\mathbf{N}$ & $\overline{\boldsymbol{x}}$ & SD & Min & Maks \\
\hline Umur ibu & 69 & 33,19 & 4,21 & 24 & 42 \\
Umur balita & 69 & 4,54 & 0,59 & 3 & 6 \\
Berat badan & 69 & 17,01 & 2,80 & 10,0 & 29,0 \\
Tinggi badan & 69 & 109,89 & 4,83 & 101,5 & 120,0 \\
\hline
\end{tabular}

\section{Tumbuh Kembang Balita}

Berdasarkan tumbuh kembang balita di PAUD Al Ikhlas sebagian besar tumbuh kembang balita baik sebanyak 44 orang $(63,8 \%)$ dan sedikit yang kurang baik yaitu 25 orang $(36,2 \%)$.

Tabel 4.3 Distribusi Frekuensi Tumbuh Kembang Balita di PAUD Al Ikhlas Keluarahan Padang Bulan Kecamatan Medan Baru Kota Medan

\begin{tabular}{lcc}
\hline $\begin{array}{c}\text { Tumbuh } \\
\text { Kembang Balita }\end{array}$ & Jumlah (n) & Persentase (\%) \\
\hline Baik & 44 & 63,8 \\
Kurang baik & 25 & 36,2 \\
\hline Jumlah & $\mathbf{6 9}$ & $\mathbf{1 0 0 , 0}$ \\
\hline
\end{tabular}

Hasil penelitian yang dilakukan pada 69 ibu yang mempunyai balita dengan menanyakan KPSP, menunjukkan bahwa pernyataan yang paling banyak dijawab tidak adalah dapatkah anak mengenakan celana panjang, kemeja, baju, atau kaos kaki tanpa dibandu? (Tidak termasuk memasang kancing, gesper, atau ikat pinggang) (pertanyaan nomor 8) sebanyak 17 orang $(24,6 \%)$ dan setelah makan, apakah anak mencuci dan mengeringkan tangannya dengan baik sehingga anda tidak perlu mengulanginya? (pernyataan nomor 2) sebanyak 13

\begin{tabular}{|c|c|c|}
\hline \multirow[t]{3}{*}{ Tabel 4.5} & \multicolumn{2}{|c|}{ Distribusi Frekuensi KPSP di PAUD Al } \\
\hline & Ikhlas Keluarahan & Padang Bulan \\
\hline & \multicolumn{2}{|c|}{ Kecamatan Medan Baru Kota Medan } \\
\hline KPSP & Jumlah (n) & Persentase (\%) \\
\hline Normal & 50 & 72,5 \\
\hline Tidak norma & 19 & 27,5 \\
\hline Jumlah & 69 & $\mathbf{1 0 0 , 0}$ \\
\hline
\end{tabular}
orang $(18,8 \%)$.

\section{Status Gizi}

Berdasarkan status gizi balita di PAUD Al Ikhlas sebagian besar status gizinya baik sebanyak 51 orang $(73,9 \%)$ dan sedikit balita dengan status gizi kurang baik yaitu 18 orang $(26,1 \%)$.

Tabel 4.6 Distribusi Frekuensi Status Gizi di PAUD Al Ikhlas Keluarahan Padang Bulan Kecamatan Medan Baru Kota Medan

\begin{tabular}{lcc}
\multicolumn{1}{c}{ Status Gizi } & Jumlah (n) & Persentase (\%) \\
\hline Baik & 51 & 73,9 \\
Kurang baik & 18 & 26,1 \\
\hline Jumlah & $\mathbf{6 9}$ & $\mathbf{1 0 0 , 0}$ \\
\hline
\end{tabular}

\section{Stimulasi Ibu}

Hasil stimulasi ibu diperoleh sebagian besar baik sebanyak 43 orang $(62,3 \%)$ dan sedikit yang kurang baik yaitu 26 orang $(37,7 \%)$.

Tabel 4.7 Distribusi Frekuensi Stimulasi Ibu di PAUD Al Ikhlas Keluarahan Padang Bulan Kecamatan Medan Baru Kota Medan

\begin{tabular}{lcc}
\hline \multicolumn{1}{c}{ Stimulasi } & Jumlah (n) & Persentase (\%) \\
\hline Baik & 43 & 62,3 \\
Kurang baik & 26 & 37,7 \\
\hline Jumlah & $\mathbf{6 9}$ & $\mathbf{1 0 0 , 0}$ \\
\hline
\end{tabular}


HubunganStatus Gizi dan Stimulasi Ibu dengan Tumbuh Kembang Balita di PAUD Al Ikhlas Keluarahan Padang Bulan Kecamatan Medan Baru Kota Medan

Balita yang status gizi baik dengan tumbuh kembang baik sebanyak 39 orang $(76,5 \%)$ dan yang kurang baik sebanyak 12 orang $(23,5 \%)$, sedangkan balita yang status gizi kurang baik dengan tumbuh kembang baik sebanyak 5 orang $(27,8 \%)$ dan yang kurang baik sebanyak 13 orang (72,2\%). Hasil uji Chi-Square diperoleh bahwa ada hubungan yang signifikan antara status gizi dengan tumbuh kembang balita dengan nilai $p<0,001$.

Tabel 4.9 Hubungan Status Gizi dengan Tumbuh Kembang Balita di PAUD Al Ikhlas Keluarahan Padang Bulan Kecamatan Medan Baru Kota Medan

\begin{tabular}{lccccccc}
\hline \multirow{2}{*}{$\begin{array}{c}\text { Status } \\
\text { Gizi }\end{array}$} & \multicolumn{2}{c}{ Tumbuh Kembang } & Baik & \multicolumn{1}{c}{$\begin{array}{c}\text { Kurang } \\
\text { baik }\end{array}$} & Jumlah & \multirow{2}{*}{$\boldsymbol{P}$} \\
\cline { 2 - 6 } & $\mathbf{N}$ & $\mathbf{\%}$ & $\mathbf{N}$ & $\mathbf{\%}$ & $\mathbf{n}$ & $\mathbf{\%}$ & \\
\hline Baik & 39 & 76,5 & 12 & 23,5 & 51 & 100,0 & \\
$\begin{array}{l}\text { Kurang } \\
\text { baik }\end{array}$ & 5 & 27,8 & 13 & 72,2 & 18 & 100,0 & $<0,001$ \\
\hline
\end{tabular}

Ibu yang stimulasi baik dengan tumbuh kembang baik sebanyak 37 orang $(86,0 \%)$ dan yang kurang baik sebanyak 6 orang $(14,0 \%)$, sedangkan ibu yang stimulasi kurang baik dengan tumbuh kembang baik sebanyak 7 orang $(26,9 \%)$ dan yang kurang baik sebanyak 19 orang $(73,1 \%)$. Hasil uji Chi-Square diperoleh bahwa ada hubungan yang signifikan antara stimulasi ibu dengan tumbuh kembang balita dengan nilai $p<0,001$.

Tabel 4.10 Hubungan Stimulasi Ibu dengan Tumbuh Kembang Balita di PAUD Al Ikhlas Keluarahan Padang Bulan Kecamatan Medan Baru Kota Medan

\begin{tabular}{lccccccc}
\hline & \multicolumn{2}{c}{ Tumbuh Kembang } & & \\
\cline { 2 - 6 } $\begin{array}{c}\text { Stimulasi } \\
\text { Ibu }\end{array}$ & Baik & \multicolumn{2}{c}{$\begin{array}{c}\text { Kurang } \\
\text { baik }\end{array}$} & Jumlah & \multirow{2}{*}{$\boldsymbol{P}$} \\
\cline { 2 - 6 } & $\mathbf{N}$ & $\mathbf{\%}$ & $\mathbf{N}$ & $\mathbf{\%}$ & $\mathbf{n}$ & $\mathbf{\%}$ & \\
\hline Baik & 37 & 86,0 & 6 & 14,0 & 43 & 100,0 & \\
Kurang & 7 & 26,9 & 19 & 73,1 & 26 & 100,0 & $<0,001$
\end{tabular}

\section{Analisis Multivariat}

Untuk menganalisis pengaruh status gizi dan stimulasi ibu terhadap tumbuh kembang balita menggunakan uji regresi logistik ganda (multiple logistic regression), karena variabel dependennya 2 kategori yaitu baik dan kurang baik. Regresi logistik ganda yaitu salah satu pendekatan model matematis untuk menganalisis pengaruh beberapa variabel independen terhadap variabel dependen kategorik yang bersifat dikotomi atau binary, dengan metode Backward LR dimasukkan secara bersamasama kemudian variabel yang nilai p>0,05 akan dikeluarkan secara otomatis dari komputer sehingga dapat variabel yang berpengaruh. Variabel yang dimasukkan dalam model prediksi regresi logistik ganda adalah variabel yang mempunyai nilai $\mathrm{p}<0,25$ pada analisis bivariatnya.

Tabel 4.7 Hasil Uji Regresi Logistik

\begin{tabular}{lccccc}
\hline \multirow{2}{*}{ Variabel } & \multirow{2}{*}{ B } & \multirow{2}{*}{ Sig } & \multirow{2}{*}{$\operatorname{Exp}(\mathbf{B})$} & \multicolumn{2}{c}{$\mathbf{9 5 , 0 \%}$ CI } \\
\cline { 5 - 6 } & & & Lower & Upper \\
\hline Status gizi & 3,655 & 0,001 & 38,650 & 4,052 & 368,703 \\
Stimulasi & 4,086 & $<0,001$ & 59,484 & 6,893 & 513,328 \\
constant & $-3,604$ & - & - & - & - \\
\hline
\end{tabular}

Berdasarkan tabel diatas didapatkan hasil bahwa status gizi dan stimulasi ibu berpengaruh terhadap tumbuh kembang balita di PAUD AL Ikhlas. Status gizi memiliki nilai $\operatorname{Exp}(\mathrm{B})=38,650(95 \% \mathrm{CI}$ $4,052-368,703)$ artinya balita yang status gizi kurang baik berpeluang 37 kali lebih besar dengan tumbuh kembang balita kurang baik dibanding balita yang status gizi baik. Stimulasi ibu memiliki nilai $\operatorname{Exp}(\mathrm{B})=$ 59,484 (95\% CI 6,893-513,328) artinya balita yang stimulasi ibu kurang baik berpeluang 59 kali lebih besar dengan tumbuh kembang balita kurang baik dibanding balita yang stimulasi ibu baik.

Nilai OverallPercentage diperoleh sebesar 84,1 yang artinya variabel status gizi dan stimulasi ibu bisa menjelaskan pengaruhnya terhadap tumbuh kembang balita di PAUD AL Ikhlas sebesar 84,1\%, sedangkan sisanya sebesar $15,9 \%$ dipengaruhi oleh faktor lain yang tidak termasuk dalam variabel penelitian ini.

\section{Pengaruh Status Gizi terhadap Tumbuh Kembang Balita di PAUD Al Ikhlas Keluarahan Padang Bulan Kecamatan Medan Baru Kota Medan}

Hasil penelitian menunjukkan bahwa masih ditemukannya balita dengan status gizi kurang baik (26,1\%). Hasil uji Chi-Square diperoleh bahwa ada hubungan yang signifikan antara status gizi dengan tumbuh kembang balita dengan nilai $p<0,001$. Balita yang status gizi kurang baik cenderung mengalami tumbuh kembang yang kurang baik dibanding balita yang status gizi baik.

Berdasarkan hasil analisis multivariat bahwa status gizi berpengaruh terhadap tumbuh kembang balita di PAUD AL Ikhlas. Status gizi memiliki nilai $\operatorname{Exp}(\mathrm{B})=$ 38,650 (95\% CI 4,052-368,703) artinya balita yang status gizi kurang baik berpeluang 37 kali lebih besar dengan tumbuh kembang balita kurang baik dibanding balita yang status gizi baik.

Masa anak dibawah lima tahun merupakan perode penting dalam tumbuh kembang anak karena pertumbuhan dasar yang berlangsung pada masa balita akan mempengaruhi dan menentukan perkembangan anak selanjutnya. Dalam pertumbuhan dan perkembangan anak memerlukan zat gizi agar proses pertumbuhan dan perkembangan berjalan dengan baik. Zat-zat gizi yang dikonsumsi anak akan berpengaruh pada status gizi anak. Perbedaan status gizi anak memiliki pengaruh yang berbeda pada setiap perkembangan anak, apabila gizi seimbang yang dikonsumsi tidak terpenuhi, pencapaian pertumbuhan dan perkembangan anak terutama perkembangan motorik yang baiak akan terhambat. 


\section{Pengaruh Stimulasi Ibu terhadap Tumbuh Kembang Balita di PAUD Al Ikhlas Keluarahan Padang Bulan Kecamatan Medan Baru Kota Medan}

Hasil penelitian menunjukkan bahwa masih ditemukannya stimulasi ibu yang kurang baik $(37,7 \%)$. Hasil uji Chi-Square diperoleh bahwa ada hubungan yang signifikan antara stimulasi ibu dengan tumbuh kembang balita dengan nilai $p<0,001$. Balita yang stimulasi ibu kurang baik cenderung mengalami tumbuh kembang yang kurang baik dibanding balita yang stimulasi ibunya baik. Hal ini dikarenakan pada kemampuan gerak kasar ibu tidak mencontohkan anak melompat tali, bermain dengan teman sebayanya, pada kemampuan gerak halus ibu tidak mengajari anak mencocokkan dan menghitung angka dengan kartu yang ditulis 1-10, pada kemampuan bicara dan bahasa ibu tidak memberikan dorongan kepada anak melengkapi kalimat dan pada kemampuan bersosialisasi dan kemandirian ibu tidak memberikan tugas rutin dalam kegiatan di rumah, memberikan dorongan kepada anak bermain dengan teman sebaya, memberikan dorongan kepada anak untuk mengutarakan persaannya, dan buat rencana jalan-jalan.

Berdasarkan hasil analisis multivariat bahwa stimulasi ibu berpengaruh terhadap tumbuh kembang balita di PAUD AL Ikhlas. Stimulasi ibu memiliki nilai Exp (B) $=59,484(95 \%$ CI 6,893-513,328) artinya balita yang stimulasi ibu kurang baik berpeluang 59 kali lebih besar dengan tumbuh kembang balita kurang baik dibanding balita yang stimulasi ibu baik.

Pendidikan orang tua berpengaruh terhadap perkembangan anak terutama pendidikan ibu. Pendidikan ibu yang rendah mempunyai risiko untuk terjadinya keterlambatan perkembangan anak, disebabkan ibu belum tahu cara memberikan stimulasi perkembangna anaknya. Ibu dengan pendidikan lebih tinggi lebih terbuka untuk mendapat informasi dari luar tentang cara pengasuhan anak yang baik, menjaga kesehatan dan pendidikan anak.,pendidikan ibu ... lebih dari SMA/SMK, cukup baik untuk mendidik anak

UNICEF (1998) mengatakan bahwa stimulasi yang diberikan oleh orang tua dan pengasuh sangat mendukung terhadap perkembangan anak yang optimal. Sementara Monks, dkk (1992) mengatakan bahwa stimulasi verbal sangat penting bagi perkembangan bahasa dalam perode pertama. Bayi-bayi yang sering diajak bicara oleh ibu-ibu mereka memiliki tingkat perkembangan yang lebih tinggi daripada bayi yang tidak mengalami perlakuan tersebut.

Jika dilihat berdasarkan kategori stimulasi maka pada umumnya perkembangan anak termasuk normal. Semakin banyak anak diberi stimulasi maka perkembangannya semakin baik. Menurut Gunarsa dan Gunarsa (1995) semakin banyak anak menerima stimulasi dari lingkungan semakin luas pengetahunnya akan optimal. Dekimikian juga Alisjahbana (2000) mengatakan bahwa perkembangan anak dapat didukung dan dirangsang dari lingkungan.

\section{Simpulan}

1. Ada pengaruh status gizi terhadap tumbuh kembang balita di PAUD Al Ikhlas Kelurahan Padang Bulan Kecamatan Medan Baru Kota Medan. Status gizi merupakan variabel yang paling besar berpengaruh terhadap tumbuh kembang balita. Balita yang status gizi kurang baik berpeluang 37 kali lebih besar dengan tumbuh kembang balita kurang baik dibanding balita yang status gizi baik. Masih ditemukannya balita yang memiliki berat badan dan tinggi badan tidak normal.

2. Ada pengaruh stimulasi ibu terhadap tumbuh kembang balita di PAUD Al Ikhlas Kelurahan Padang Bulan Kecamatan Medan Baru Kota Medan. Balita yang mendapat stimulasi ibu kurang baik berpeluang 59 kali lebih besar dengan tumbuh kembang balita kurang baik dibanding balita yang stimulasi ibu baik. Balita kurang baik mendapat stimulasi ibu dari kemampuan bersosialisasi dan kemandirian yaitu kurang memberikan tugas rutin dalam kegiatan di rumah, kurang memberikan dorongan kepada anak bermain dengan teman sebaya, kurang memberikan dorongan kepada anak untuk mengutarakan persaannya, dan buat rencana jalanjalan.

\section{Saran}

1. Diperlukan upaya menyeluruh untuk menjaga tumbuh kembang anak sedini mungkin sejak dalam kandungan sampai usia lima tahun. Pemberian stimulasi diperlukan sesuai usia anak.

2. Meningkatkan peran-serta ibu untuk selalu mendapat informasi mengenai perkembangan anak, sehingga apabila terjadi kecurigaan adanya gangguna atau keterlambatan sedini mungkin untuk dideteksi perkembangnnya.

\section{DAFTAR PUSTAKA}

Dianita, dkk, 2014, Studi Tentang Faktor - Faktor Yang Mempengaruhi Pertumbuhan Dan perkembangan Pada Balita di Desa Pengalangan Rw 03 Menganti Gresik, Surabaya

Dinas Kesehatan Kota Medan, 2012. Profil Kesehatan kota Medan tahun 2011. Medan.

Dinas Kesehatan Provinsi Sumatera Utara, 2012. Profil Kesehatan Provinsi Sumatera Utara Tahun 2010. Medan.

Departemen Kesehatan RI, 2006. Pedoman Umum Pengelolaan Posyandu. Jakarta

2006. Buku Kader Posyandu dalam Usaha Perbaikan Gizi Keluarga. Jakarta.

Hidayat, A., 2011. Metode Peneltian Kesehatan Paradigma Kuantatif, Health Books, Surabaya.

Kementerian Kesehatan RI, 2013. Riset Kesehatan Dasar (RISKESDAS) 2013, Jakarta. 
2014a, Instrumen Stimulasi, Deteksi dan Intervensi Dini Tumbuh Kembang, Kemenkes, Jakarta.

2014b, Pedoman

Pelaksanaan Stimulasi, Deteksi Dini dan Intervensi Dini Tumbuh Kembang Anak di Tingkat Pelayanan Kesehatan Dasar, Jakarta.

Helen, B, 2010, Early Childhood Stimulation Interventions in Developing Countries: A comprehensive literature review, BID

Lindawati, 2013, Faktor-Faktor yang Berhubungan Dengan Perkembangan Motorik Anak Usia Sekolah, Jakarta

Mahesa , 2013 , Gambaran Hasil Pelaksanaan KPSP, TDL, TDD Anak Usia 4 Tahun Di Wilayah Kerja Puskesmas Wiradesa Kabupaten Pekalongan, Stikes Muhamdiyah, Pekalongan

Marmi, 2012, Asuhan Neonatus Bayi, Balita, dan anak prasekolah, pustaka Pelajar, Yogyakarta.

Nasir, A.,Muhith, A., Ideputri, M.E., 2011. Buku Ajar, Metode Penelitian Kesehatan, Konsep Pembuatan Karya Tulis dan Thesis untuk Mahasiswa Kesehatan, Nuha Medika, Yogyakarta.
Ridwan, 2005. Skala Pengukuran Variabel-veriabel Penelitian. Penerbit Alfabeta. Jakarta.

Supariasa, I.D.N, 2002. Penilaian Status Gizi. EGC, Jakarta

Sugiyono, 2008. Metode penelitian Kuantitatif kualitatif dan $R \& D$. Penerbit Alfabeta. Bandung.

Soetjiningsih, 2010. Tumbuh Kembang Anak. EGC, Jakarta.

WHO , 2015 , Integrating Early Childhood Development (ECD) activities into nutrition programmes in Emergency, Why, what and How. 